\title{
Correction to: Determination of genetic diversity of natural sage populations in Muğla region of Turkey
}

\section{Altindal ${ }^{1}$}

Published online: 18 February 2019

(c) Islamic Azad University (IAU) 2019

\section{Correction to: \\ International Journal of Environmental Science and Technology \\ https://doi.org/10.1007/s13762-019-02208-7}

The article "Determination of genetic diversity of natural sage populations in Muğla region of Turkey", written by D. Altindal, was originally published electronically on the publisher's internet portal (currently SpringerLink) on 05 January 2019 with open access. With the author(s)' decision to step back from Open Choice, the copyright of the article changed on January 2019 to (C) Islamic Azad University (IAU) 2019 and the article is forthwith distributed under the terms of copyright.

The original article can be found online at https://doi.org/10.1007/ s13762-019-02208-7.

D. Altindal

daltindal@gmail.com

1 Department of Crop and Animal Production, Organic Farming Programme, Fethiye Ali Sıtkı Mefharet Koçman Vocational School, Muğla Sitkı Koçman University, Muğla, Turkey 